\title{
Screening for phosphate-solubilizing fungi from colombian andisols cultivated with coffee (Coffea arabica L.)
}

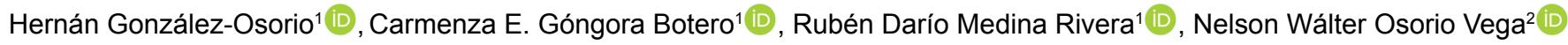

${ }^{1}$ Centro Nacional de Investigaciones de Café/CENICAFE, Chinchiná, Colombia

${ }^{2}$ Universidad Nacional de Colombia, Medellín, Colombia

Contact authors: hernan.gonzalez@cafedecolombia.com, carmenza.gongora@cafedecolombia.com, ruben.medina@cafedecolombia.com, nwosorio@gmail.com

Received in November 6, 2019 and approved in June 15, 2020

\section{ABSTRACT}

Phosphate $(P)$ bioavailability is severely constrained in volcanic ash soils due to its high fixation rate. To overcome this problem the use of P-solubilizing fungi (PSF) has been proposed gaining recently great attention. To provide a better understanding of the dynamics of PSF in soils and to establish criteria for screening effective PSF a series of studies were conducted. PSF were isolated from coffee plantations grown in a Typic Udivitrand (QU), a Pachic Fulvundand (CH), and a Typic Melanudand (Ti). Fifty-five isolates (28 from CH, 19 from Ti, and 8 from QU) produced index of $\mathrm{P}$ solubilization among 16 and $10610^{-6} \mathrm{~kg} \mathrm{dm}^{-3}$ using as $\mathrm{P}$ source phosphate rock. The results suggest that the microbial $\mathrm{P}$ solubilization was not only associated to the decrease in the culture medium $\mathrm{pH}$, but also the production of organic acids is associated with the most effective PSF. The higher production of organic acids seems to be associated with a lower fungal colony growth rate likely due to a carbon/energy drainage. The soil P-fixation capacity, soil organic content and degree of humification seems to control the relative abundance of PSF in the soils tested. In soils cultivated with coffee Phlebia gender is reported, for the first time, as a PSF.

Key words: Colombian coffee zone; soil fertility; phosphorus fixation; organic acids; humificaction degree; Phlebia.

\section{INTRODUCTION}

Phosphorus $(\mathrm{P})$ is the least available of all the essential nutrients required by plants in the different agricultural areas of the world, particularly in volcanic ash soils, where their chemical properties cause a strong $\mathrm{P}$ fixation (Velásquez et al., 2016; Shoji; Takahashi, 2002). Thus, although the organic and inorganic $\mathrm{P}$ fractions are abundant in these soils (Miller; Arai, 2017), they are not bioavailable for crop plants (Bünemann, 2015). To alleviate this the application of soluble phosphate fertilizers has been commonly used (Roy et al., 2017); however, this practice is ineffective, expensive, and carries the risk of water pollution (Tian et al., 2017). The increasing demand for $\mathrm{P}$ fertilizers and the projected decrease in their mineral $\mathrm{P}$ reserves (International Fertilizer Association - IFA, 2013; Wendling et al., 2013) indicate that the continuous use of high rates of them may not be sustainable over time. In addition, the use of strong acids to industrially produce soluble $\mathrm{P}$ fertilizers increases production costs and generates environmental risks (Matta et al., 2017; Belboom; Szöcs; Léonard, 2015; Al-Thyabat; Zhang, 2015; Cordell; Drangert; White, 2009).

Some soil microorganisms are well known to solubilize P- compounds and improve their P bioavailability for plants (Estrada et al., 2017; Adeleke; Nwangburuka; Oboirien, 2017, Jain; Singh, 2016, Khan et al., 2010). Soil P solubilizing fungi (PSF) are considered more effective than bacteria in this regard (Whitelaw, 1999). The solubilization of the soil organic $\mathrm{P}$ fraction is conducted through phosphatase enzymes (Lazo;
Dyer; Alorro, 2017; Jain; Singh, 2016), whereas the dissolution of mineral phosphates is carried out via the secretion of organic acids from the oxidative respiration of carbonaceous compounds (Wyciszkiewicz et al., 2016; Acevedo et al., 2014; Osorio; Habte, 2014a; Osorno; Osorio, 2014b; Oliveira et al., 2014; Haq; Ali; Iqbal, 2003). The PSF have been reported to significantly promote plant growth and $\mathrm{P}$ uptake in plants grown in man-made substrates (soil:sand:organic materials) as well as in soils with low to high P sorption capacity (Entisols, Alfisols, Oxisols, and Ultisols), but they have been ineffective to do so in soils with very high $\mathrm{P}$ sorption capacity (Andisols) (Osorio, 2011).

In despite promissory effects reported by using P solubilizing microorganisms on plant performance (Saravanakumar; Arasu; Kathiresan, 2013; Xiao et al., 2008; Stamford et al., 2007; Dwivedi; Singh; Dwivedi, 2004), the use of this biotechnological application in crop field is still limited (Khan et al., 2010). This is partially due to the uncertainty of extrapolate results obtained in different soil and crop conditions (Owen et al., 2015). At the end, this is associated to the lack of understanding on the soil variables involved in the screening of these microorganisms and the influence of environmental variables from the sites in which they are isolated (Zhao; Zhang, 2015). In addition, simple and low-complexity procedures (Rolewicz; Rusek; Borowik, 2017) must be developed to produce adequate microbial formulations for use in soil-plant systems. It is believed that it is more convenient to use native microorganisms to the study area 
because they are already associated with the cultivated plants of interest and are well adapted to the soil conditions (Mora et al., 2017, Mahecha; Sierra; Posada, 2017). Thus, the soil properties that control the presence and activity of PSF should be determined.

The hypothesis of this study was that the relative abundance of effective PSF in dissolving phosphate rock is greater in soils with higher P fixing capacity. This should be considered as a tool to understand the solubilization dynamics of PSF in soils and establishing the criteria for an effective bioprospection of these microorganisms. Thus, the aim of this study was to isolate, identify and evaluate PSF from the rhizosphere of coffee plantations in Andisols with different P-fixing capacities and to establish the relationship between this characteristic and the relative abundance of these microorganisms.

\section{MATERIAL AND METHODS}

\subsection{Classification and soil properties of the sites under study}

The study was conducted in the soil microbiology laboratory of the National Coffee Research Center (CENICAFE), located in the Plan Alto district of Chinchiná, Colombia $\left(5^{\circ} 15^{\prime} 34^{\prime}\right.$ ' N, 75 $15^{\prime} 34^{\prime}$ ' W, altitude of $1430 \mathrm{~m}$ ).

Three farms cultivated with coffee for at least 20 years were selected, their soils (Quindío, Chinchiná and Timbío) were classified as Andisols (Table 1), which exhibited different $\mathrm{P}$ fixation capacities. Some soil properties, including organic matter (OM) content and melanic index (MI) were determined. The soil samples $(0.5 \mathrm{~kg})$ were collected from 20 plant at the soil rhizosphere in the first 0.3 $\mathrm{m}$ of soil after four months since last fertilization. During the cultivation of coffee these farms had followed CENICAFÉ recommendations for crop management such as no use of herbicides for weed control, fertilization based on soil tests, and soil conservation practices (Federación Nacional de Cafeteros de Colombia - FNC, 2013).

For each soil, isotherms of soil P fixation were performed following the procedure proposed by Fox and Kamprath (1970). To this purpose, $3 \mathrm{~g}$ of soil (dry base) were transferred into centrifuge plastic tube $\left(50 \mathrm{~cm}^{3}\right)$ and received increasing amounts of $\mathrm{KH}_{2} \mathrm{PO}_{4}$ dissolved in $0.01 \mathrm{M} \mathrm{CaCl}_{2} .2 \mathrm{H}_{2} \mathrm{O}$ at a $\mathrm{P}$ rate of $0,500,1000,2000,3000 \times 10^{-6} \mathrm{~kg} \mathrm{dm}^{-3}$. Two drops of toluene were added to each tube to inhibit microbial activity. The tubes were shaken $(100 \mathrm{rpm})$ in a reciprocal shaker for 6 $\mathrm{d}$, twice a day, $30 \mathrm{~min}$ each time. After that, the tubes were centrifuged (4500 rpm, $15 \mathrm{~min}$ ) and the supernatant liquid was filtered (Whatman No. 42 filter paper). In $10 \mathrm{~cm}^{3}$ of the filtrate the soil solution $\mathrm{P}$ concentration was measured using the phosphomolybdate method. The $\mathrm{P}_{0.2}$ value (amount of $\mathrm{P}$ in $10^{-6} \mathrm{~kg} \mathrm{dm}^{-3}$ required to achieve a soil solution $\mathrm{P}$ concentration of $0.2 \times 10^{-6} \mathrm{~kg} \mathrm{dm}^{-3}$ ) was calculated and with this the soil $\mathrm{P}$ fixation category was obtained based on the proposal of Juo and Fox (1977).

\subsection{Isolation of microorganisms}

From each of selected soils samples, $10 \mathrm{~g}$ (dry basis) were transferred into a flask containing $90 \mathrm{~cm}^{3}$ of a sterile $\mathrm{NaCl}$ solution $(0.85 \%)$ and mixed for $3 \mathrm{~h}$ at $120 \mathrm{rpm}$. This initial dilution $\left(10^{-1}\right)$ was serially diluted until to obtain a $10^{-6}$ dilution using in each turn $1 \mathrm{~cm}^{3}$ and $9 \mathrm{~cm}^{3}$ of the $\mathrm{NaCl}$ solution. Next, an aliquot of $0.1 \mathrm{~cm}^{3}$ of each dilution was transferred aseptically into Petri dishes containing potato dextrose agar (PDA) plus chloramphenicol $(0.15 \%)$ as an antibacterial agent. The dishes were incubated for seven days at $28^{\circ} \mathrm{C}$, after which the fungal colonies were aseptically transferred into modified Pikovskaya medium (Pikovskaya, 1948) containing chloramphenicol $\left(1.5 \mathrm{~g} \mathrm{dm}^{-3}\right)$, bromocresol purple $(0.05 \%)$, glucose $(1.0 \%)$ as a carbon source, and Huila phosphate rock $\left(3.5 \mathrm{~g} \mathrm{dm}^{-3}\right)$ as the only source of $\mathrm{P}$. The chemical composition of the phosphate rock (in \%) according to the manufacturer's label was: $33.7 \mathrm{P}_{2} \mathrm{O}_{5}, 45.5 \mathrm{CaO}, 10.96 \mathrm{SiO}_{2}, 2.11 \mathrm{~F}, 0.54$ $\mathrm{Al}_{2} \mathrm{O}_{3}, 0.45 \mathrm{Fe}_{2} \mathrm{O}_{3}, 0.11 \mathrm{MgO}$, and $0.3 \mathrm{SO}_{4}$. The Petri dishes containing the strains were incubated at $28^{\circ} \mathrm{C}$ for $10 \mathrm{~d}$.

\subsection{Identification of fungal colonies with $P$ solubilization capacity}

The fungi obtained from the previous procedure that exhibited a violet halo around their colonies were chosen and aseptically transferred into $250 \mathrm{~cm}^{3}$ Erlenmeyer flask (experimental unit) containing $50 \mathrm{~cm}^{3}$ of Pikovskaya's modified broth (Pikovskaya, 1948). For this, $1.0 \mathrm{~cm}^{3}$ of a solution containing fungal spores $\left(10^{7}\right.$ spores per $\left.\mathrm{cm}^{3}\right)$ of each isolate was separately inoculated into the flasks.

Table 1: Classification and selected soil of the sites under study.

\begin{tabular}{|c|c|c|c|}
\hline \multirow{2}{*}{ Soil } & \multirow{2}{*}{ USDA soil taxonomy } & \multicolumn{2}{|c|}{ Location } \\
\hline & & Department & Town \\
\hline Quindío (QU) & Typic Udivitrand & Quindío & Buenavista / Río Verde \\
\hline Chinchiná $(\mathrm{CH})$ & Pachic Fulvudand & Caldas & Chinchiná/ La Quiebra \\
\hline Timbío (Ti) & Typic Melanudand & Cauca & Timbío/ San Joaquín \\
\hline
\end{tabular}


An uninoculated culture was used as an absolute control (control). Another positive control-reference strain was established with the fungus Paecilomyces lilacinus, which has been reported as a PSF (Arrieta et al., 2015). This fungus was provided by the company Soluciones Microbianas del Trópico (www.smdeltropico.com).

After incubation for seven days at $28{ }^{\circ} \mathrm{C}$ and 80 $\mathrm{rpm}$, the experimental units were centrifuged at $4000 \mathrm{rpm}$ for $15 \mathrm{~min}$ and the supernatant liquid was filtered through a Whatman No. 42 filter paper. The final pH of the medium was determined through a potentiometer (Mettler Toledo). Aliquots of the filtrate $\left(10 \mathrm{~cm}^{3}\right)$ were withdrawn into test tubs to determine the concentration of $\mathrm{P}$ in solution $\left(\mathrm{mg} \mathrm{dm}^{-3}\right)$ using the phosphomolybdate method with a wavelength of $420 \mathrm{~nm}$.

The data were subjected to descriptive analysis (average and standard error) and then to analysis of variance using a completely randomized model and to the Dunnett's mean separation test. The relationship between solution $\mathrm{P}$ and $\mathrm{pH}$ was evaluated using a Pearson correlation analysis $(P \leq 0.05)$. In all tests a level of significance $(P$-value $\leq 0.05)$ was used.

The isolates were classified in four P-solubilizationcategories according to the final solution $\mathrm{P}$ concentration (in $10^{-6} \mathrm{~kg} \mathrm{dm}^{-3}$ ): < 40: low; 40-60: medium; 60-90: high; and > 90 very high (González, 2018).

\subsection{Determination of organic acids}

Nine fungal isolates from different P-solubilizationcategories were selected to detect the organic acid production, as follow: two isolates belong to low P-solubilization, three correspond to intermediate P-solubilization, two to high and two correspond to very high P-solubilization category.

To this purpose, $1.0 \mathrm{~cm}^{3}$ of a solution that contained a concentration of $10^{7}$ spores $\mathrm{cm}^{-3}$ was inoculated into a 250 $\mathrm{cm}^{3}$ Erlenmeyer flask containing $50 \mathrm{~cm}^{3}$ of Pikovskaya's modified medium; the flasks were incubated at environmental temperature (from 20 to $22{ }^{\circ} \mathrm{C}$ ) for 7 days at $80 \mathrm{rpm}$. The samples were analyzed in the Instrumental Analysis laboratory of the Universidad Nacional de Colombia at Medellin. The concentration of the most common acids that HSP produced: malic, oxalic, tartaric, citric, succinic, and lactic organic acids was determined on these samples using the method of Aung and Ting (2005). Thus, the liquid medium was centrifuged at 4500 rpm for $15 \mathrm{~min}$, then filtered through a $0.22-\mu \mathrm{m}$ membrane and injected into an Agilent 1100 series HPLC coupled to a $\mathrm{UV} / \mathrm{Vis}$ detector. The mobile phase consisted of a solution of $0.05 \%$ ortho-phosphoric acid using a SUPELCOGEL $\mathrm{H}$ column $(78 \times 300 \mathrm{~mm})$. In all cases, calibration curves were obtained yielding coefficients of determination $\left(r^{2}\right)>0.99$.

\subsection{Phosphate solubilizing fungi growth rate}

The growth rate of four PSF colonies which were effective in solubilizing $\mathrm{P}\left(>40 \times 10^{-6} \mathrm{~kg} \mathrm{dm}^{-3}\right)$ and that exhibited differences in the concentration and type of organic acids produced (according to the test described) was monitored. In this way, a $0.01 \mathrm{~cm}^{3}$ aliquot of each PSF was transferred (concentration $1 \times 10^{7}$ spores $\mathrm{cm}^{-3}$ ) into the center of a Petri dish containing PDA plus lactic acid $(0.1 \%)$ as a bactericidal agent. The diameter of the colonies was measured after 2, 4, $6,8,10,12,14$, and 15 days. There were 12 replicates (dishes) for each PSF. Through descriptive data analysis, the daily average growth was estimated for each selected fungus. The $5 \%$ confidence intervals were calculated.

\subsection{Determination of phosphate-solubilizing fungi species}

The genus and species of the four PSF assayed for growth rate were determined by sequencing the internal transcribed spacer (ITS) regions 1 and 2 of the ribosomal DNA. For the PSF being assayed, a single colony was inoculated into $5 \mathrm{~cm}^{3}$ of potato dextrose broth (PDB) and incubated at $28-30{ }^{\circ} \mathrm{C}$ with agitation at $150 \mathrm{rpm}$ until reaching the logarithmic growth phase. Subsequently, to recover the biomass, the culture was centrifuged in liquid medium for $10 \mathrm{~min}$ at $2500 \mathrm{rpm}$, and the resulting pellet was washed twice with sterile $0.85 \%$ saline, centrifuging it each time to clean the mycelia. Subsequently, $100 \mathrm{mg}$ of tissue was used for DNA extraction using a DNeasy Plant Mini Kit ${ }^{\circledR}$ Genomic DNA (Qiagen ${ }^{\circledR}$, USA) following the recommended protocol for fungi.

The efficiency of the DNA extraction process was verified by electrophoresis in a $1 \%$ agarose gel with ethidium bromide stain, $\lambda / H i n d I I I$ phage used as the molecular weight marker. For DNA quantification and quality estimation, a Nanodrop 2000c was used to verify that the 260/280 nm ratio was between 1.8 and 2.0 and the $260 / 230 \mathrm{~nm}$ ratio was between 1.8 and 2.2 .

The ITS1 and ITS2 intergenic regions and the 5.8S ribosomal subunit of the isolates were amplified from the genomic DNA using universal primers ITS 5, (5'-GGAAGTAAAAGTCCTAACAAG-3') and ITS4 (5'-TCCTCCGCTTATTGATATGC-3') to amplify a fragment of approximately $600 \mathrm{bp}$. The reactions had a final volume of 0.025 $\mathrm{cm}^{3}\left(1 \times\right.$ PCR buffer, $0.2 \mathrm{mM}$ dNTPs, $1 \mathrm{mM} \mathrm{MgCl}{ }_{2}, 0.0005 \mathrm{mM}$ primers, $1 \mathrm{U}$ recombinant Taq DNA polymerase (Invitrogen ${ }^{\circledR}$ ) and $100 \mathrm{ng}$ of bacterial DNA). The reactions were incubated in a PTC-100 thermocycler (Bio Rad ${ }^{\circledR}$, USA) using the following PCR amplification program: an initial denaturation at $95^{\circ} \mathrm{C}$ for 10 min, followed by 35 cycles of 1 min of denaturation at $92^{\circ} \mathrm{C}$ and an incubation at $72{ }^{\circ} \mathrm{C}$ for $2 \mathrm{~min}$ The PCR products were analyzed by electrophoresis in a $1 \%$ agarose gel with ethidium bromide stain. Then the PCR products were cleaned using PureLink ${ }^{\mathrm{TM}}$ PCR purification kit (Thermo Fisher SCIENTIFIC). The sequencing of the PCR products was performed by Macrogen ${ }^{\circledR}$ (South Korea), to which vials containing approximately $0.1 \mathrm{mg} \mathrm{cm}^{-3}$ of the products of each PCR were sent. 
Quality analysis was performed on the obtained sequences using CLC $^{\circledR}$ Main Workbench (Qiagen Company, USA), with a Phred value of greater than 30 per base used as the acceptance criterion and a window with 50 bases lower than the Phred value and a size less than 500 bases used as rejection criteria.

Finally, the sequences were compared to the NCBI nucleotide database using BLASTn version 2.2.27+ (Altschul et al., 1990). The sequence similarity was obtained with e-value of $1 \times 10^{-5}$. These results were filtered based on $80 \%$ similarity and $80 \%$ coverage of the region that was being amplified with the primers described in the previous section.

\subsection{Association between the proportion of PSF and $\mathrm{P}$ fixation capacity in soil}

From each soil, an aliquot of $0.1 \mathrm{~cm}^{3}$ of the $10^{-4}$ dilution was aseptically transferred into Petri dish.

The dishes contained the modified Pikovskaya medium described above. After incubation for five days, the total number of fungal strains that grew was quantified, distinguishing those that exhibited color changes in the medium surrounding the colony (considered PSF) from those that did not exhibit this characteristic (other fungi); the proportion of PSF were determined. The procedure had 12 replicates. Subsequently, data were subjected to an analysis of variance and to the multiple range test of Duncan for mean separation $(P \leq 0.05)$.

All of the analyses and statistical tests described in this study were performed using the statistical package SAS version $9.4^{\circ}$ (2016 by SAS Institute Inc. Cary NC, USA).

\section{RESULTS AND DISCUSSION}

\subsection{Identification of fungal colonies with $\mathrm{P}$ solubilization capacity}

Fifty-five fungal isolates capable of solubilizing phosphate rock were detected (Figure 1): 28 from Chinchiná (CH), 19 from Timbío (Ti), and 8 from Quindío (QU). The uninoculated control had a mean solution $\mathrm{P}$ concentration of $3.9 \times 10^{-6} \mathrm{~kg} \mathrm{dm}^{-3}$, whereas the reference fungus $P$. lilacinus the mean value was $38.2 \times 10^{-6} \mathrm{~kg} \mathrm{dm}^{-3}$. A total of 24 isolates had $\mathrm{P}$ solubilization levels significantly higher than $P$. lilacinus.

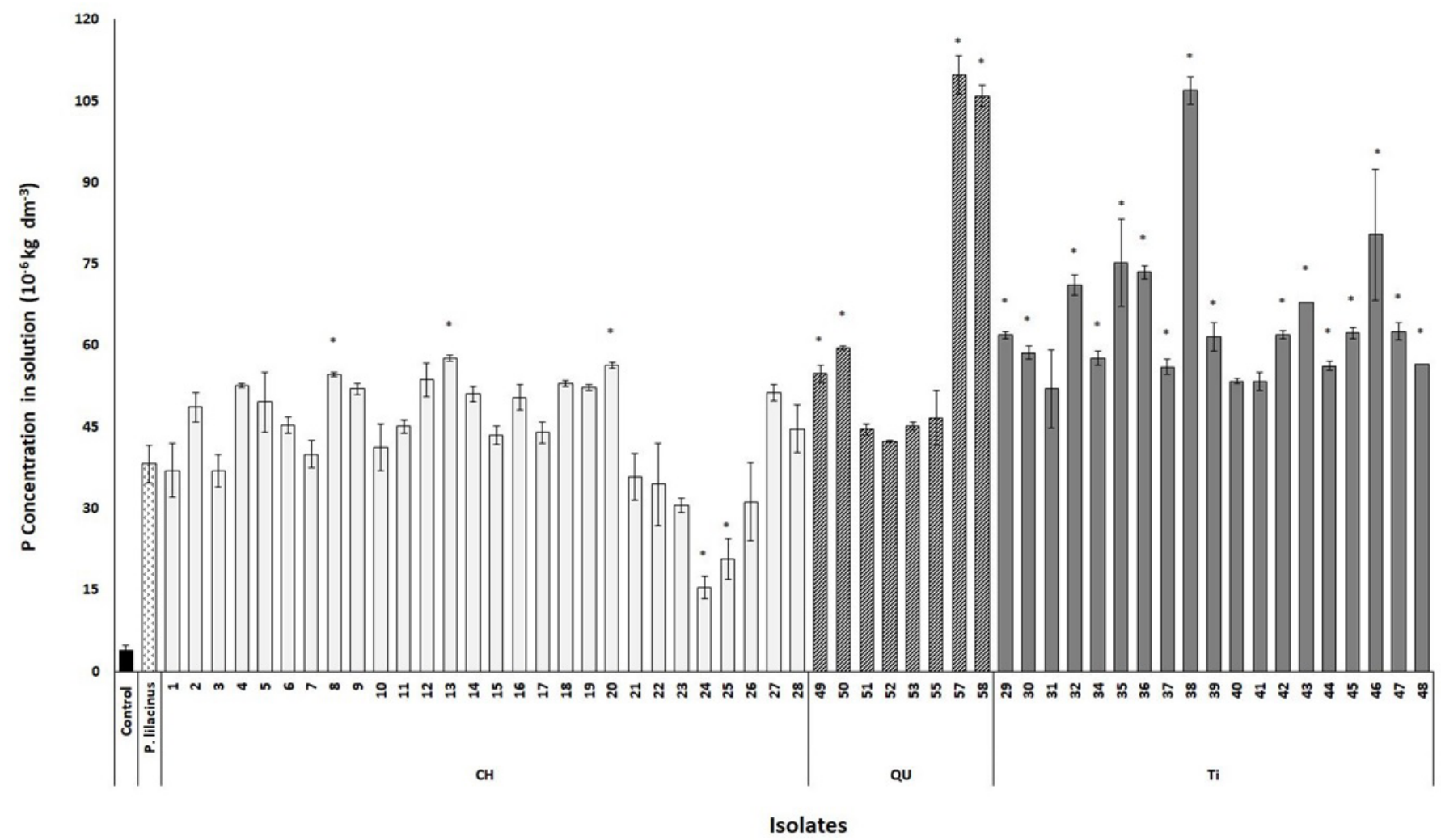

Figure 1: Final solution $\mathrm{P}$ concentration $\left(10^{-6} \mathrm{~kg} \mathrm{dm}^{-3}\right)$ as a function of the inoculation with fungal strains isolated from three soils of the central coffee-growing zone of Colombia ( $\mathrm{CH}$ : Chinchiná; QU: Quindío; and Ti: Timbío). An uninoculated control and the inoculation with the fungus $P$. lilacinus were included as references. The bars indicate the standard error. The asterisk indicates highly significant differences of the respective treatment compared to $P$. lilacinus inoculation, according to the Dunnett's test $(P<0.0001)$. 
Studies of microbial-mediated $\mathrm{P}$ solubilization in the laboratory have produced different results depending on the PSF used or the mineral $\mathrm{P}$ source. For instance, Aspergillus niger solubilized $\mathrm{P}$ to a value of $2540 \times 10^{-6} \mathrm{~kg} \mathrm{dm}^{-3}$ from Caphosphates (Acevedo et al., 2014). Similarly, Zhao and Zhang (2015) observed that Trichoderma asperellum solubilized P to reach $160 \times 10^{-6} \mathrm{~kg} \mathrm{dm}^{-3}$ from tricalcium phosphate and dibasic calcium phosphate. Mittal et al. (2008) reported P solubilization values of 760 and $148 \times 10^{-6} \mathrm{~kg} \mathrm{dm}^{-3}$ when inoculated tricalcium phosphate and phosphate rock with A. awamori and Penicillium citrinum, respectively. Finally, Osorno and Osorio (2014) documented $\mathrm{P}$ solubilization levels of 80 and $120 \times 10^{-6} \mathrm{~kg} \mathrm{dm}^{-3}$ from phosphate rock inoculated with $A$. niger and Mortierella sp.

The differences in the results obtained in this study respect to those reported in the literature, apart from being associated with the source of $\mathrm{P}$, can be primarily explained according to the type of microorganism being studied, components of the culture medium used, and the incubation time used for the solubilization process. For instance, Wyciszkiewicz et al. (2016) described that the P solubilization depended on the P-containing source. This issue should be considered during the selection of potential PSF to solubilize P from a particular low soluble P mineral.

In the uninoculated control the solution $\mathrm{pH}$ was 6.4, while with the fungal inoculations this ranged between 3.0 and
4.2, including P. lilacinus (Figure 2). Only four strains showed statistically higher $\mathrm{pH}$ values than P. lilacinus $(\mathrm{CH} 21, \mathrm{CH} 3$, $\mathrm{CH} 7$, and TI43), and at the same time higher P solubilization.

One of the primary mechanisms involved in the microbial-mediated $\mathrm{P}$ solubilization of poorly soluble minerals is related to the decrease in $\mathrm{pH}$ (Saravanakumar; Arasu; Kathiresan, 2013). This reaction (Equation 1) is chemically viable and involves the contribution of $\mathrm{H}^{+}$secreted by the PSF due to its metabolic processes associated to their growth and development (Khan et al., 2010).

$$
\mathrm{Ca}_{5}\left(\mathrm{PO}_{4}\right)_{3} \mathrm{OH}+7 \mathrm{H}^{+} \leftrightarrows 5 \mathrm{Ca}^{2+}+3 \mathrm{H}_{2} \mathrm{PO}_{4}^{-}+\mathrm{H}_{2} \mathrm{O} K=10^{14.5}
$$

Free energy yield: $-82 \mathrm{~kJ} \mathrm{~mol}^{-1}$

Since the results showed that the uninoculated control had a $\mathrm{pH}$ 0f 6.2, while the PSF inoculation decreased it down below 4.2 (Figure 2), this seems to validate the theory that a reduction in $\mathrm{pH}$ is a determining factor in the microbial solubilization of $\mathrm{P}$ from phosphate rock. However, the relationship between solution $\mathrm{P}$ and solution $\mathrm{pH}$ was not entirely consistent (Figure 3). For instance, the cluster of strains most effective were Ti38, Q57, and QU58 with $\mathrm{pH}$ values between 3.0 and 3.8. However, some PSF such as CH28 had lower values of solution $\mathrm{pH}$ (3.2) and had a P solubilization value of only $45 \times 10^{-6} \mathrm{~kg} \mathrm{dm}^{-3}$.

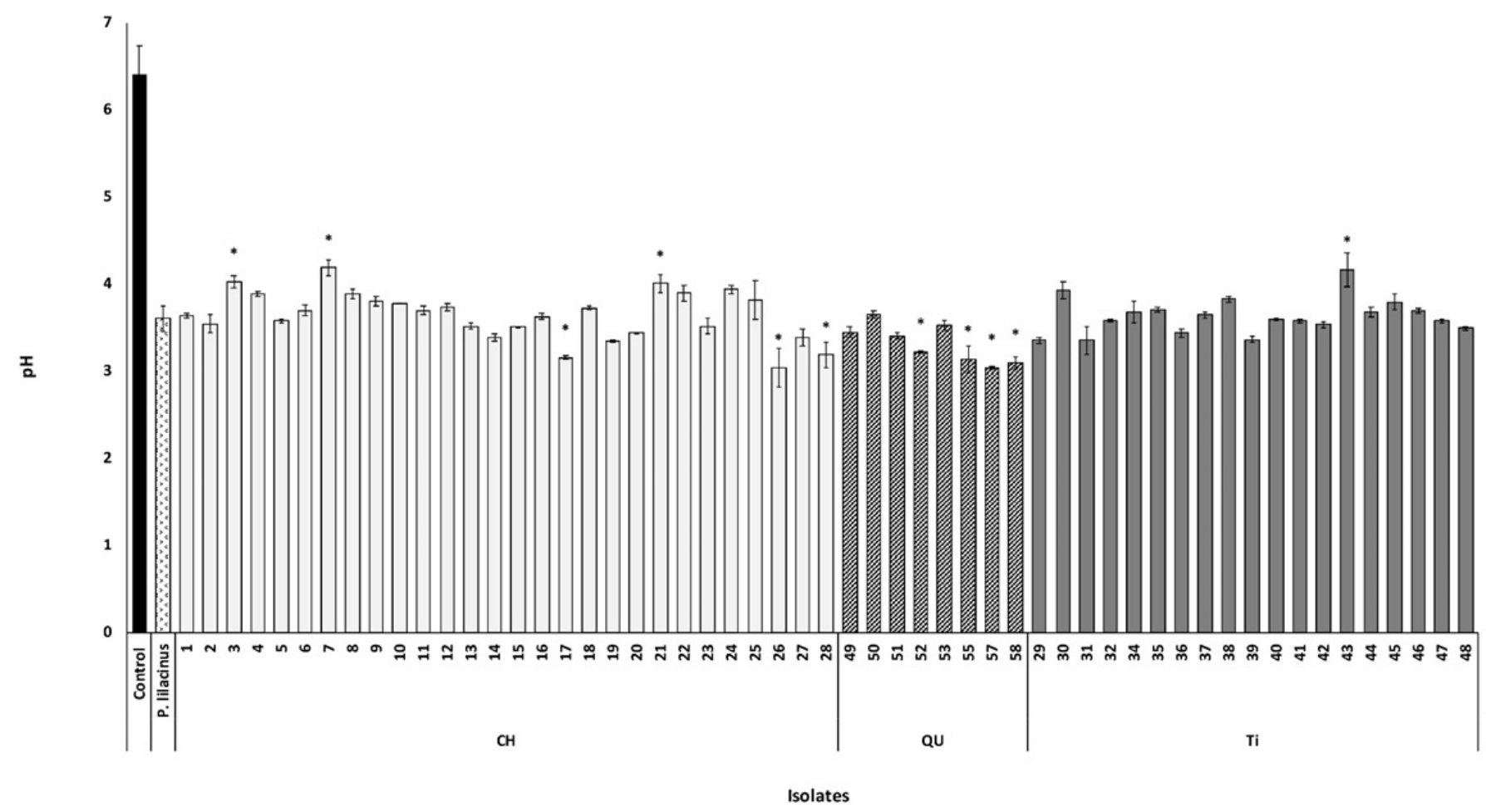

Figure 2: Final solution $\mathrm{pH}$ values as a function of the inoculation with fungal strains isolated from three soils of the central coffee-growing zone of Colombia ( $\mathrm{CH}$ : Chinchiná; QU: Quindío; and Ti: Timbío). An uninoculated control and the inoculation with the fungus $P$. lilacinus were included as references. The bars indicate the standard error. The asterisk indicates highly significant differences of the respective treatment compared to $P$. lilacinus inoculation, according to the Dunnett's test $(P<0.0001)$. 


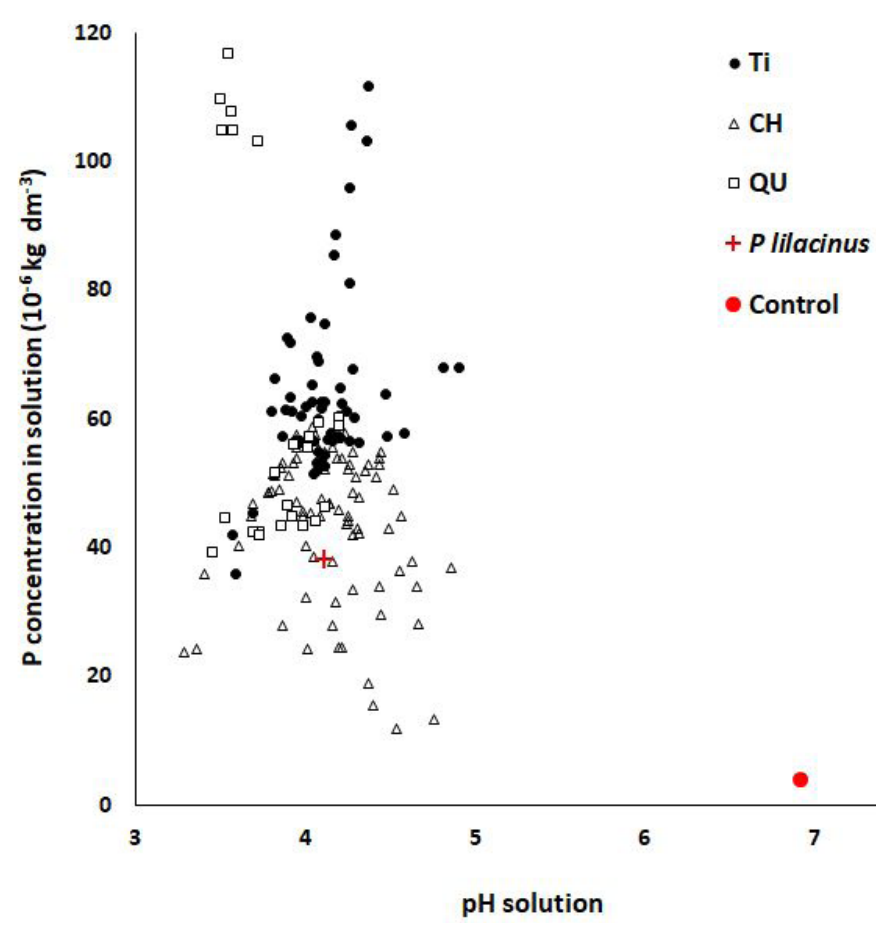

Figure 3: Concentration of $P$ in solution in relation to the final solution $\mathrm{pH}$ obtained $10 \mathrm{~d}$ after the inoculation with the soil fungi. The fungi were isolated from three soils of the central coffee-growing region of Colombia $(\mathrm{CH}$ : Chinchiná, Ti: Timbío, and QU: Quindío).

It is clear that the decrease of $\mathrm{pH}$ contributes to the dissolution of phosphate rock, but it is not the only factor that influences the $\mathrm{P}$ solubilization process. For this reason, the production and release of organic acids by the selected fungal strains was evaluated as indicated below.

\subsection{Determination of organic acids}

The nine selected strains were classified in four categories according to the $\mathrm{P}$ solubilization values (González, 2018): Low (<40 x $\left.10^{-6} \mathrm{~kg} \mathrm{dm}^{-3}\right)$ : $\mathrm{CH} 23, \mathrm{CH} 24$; Intermediate (40-60 x 10-6 $\left.\mathrm{kg} \mathrm{dm}^{-3}\right)$ : CH4, CH15, CH2O; High (60-90 x $\left.10^{-6} \mathrm{~kg} \mathrm{dm}^{-3}\right)$ : Ti32, Ti43; Very high $\left(>90 \times 10^{-6} \mathrm{~kg} \mathrm{dm}^{-3}\right)$ : Q57, Ti38. The organic acids analysis for the nine selected PSF strains allowed to find that: malic and oxalic acids were not detected, tartaric and citric acids were produced by four of the nine strains, succinic acid was generated by two of them. Lactic acid was the most commonly detected acid, being produced by $77.7 \%$ of the strains (Figure 4 ).

The PSF strains with low $\mathrm{P}$ solubilization activity produced monocarboxylic lactic acid. The strains categorized as intermediate in $\mathrm{P}$ solubilization, had different types and concentrations of organic acids with respect to those of the first category such as: tartaric and succinic acids (dicarboxylic acids) and citric acid (tricarboxylic acid). The PSF classified in the high solubilization category produced citric and tartaric acids. As well as a greater diversity and concentration of organic acids, predominantly tartaric acid, followed by citric acid.

In this way, the effectiveness of PSF's in dissolving $\mathrm{P}$ from phosphate rock depends on, besides the solution $\mathrm{pH}$ decrease, both the diversity and concentration of organic acids that they may be produced during its growth.

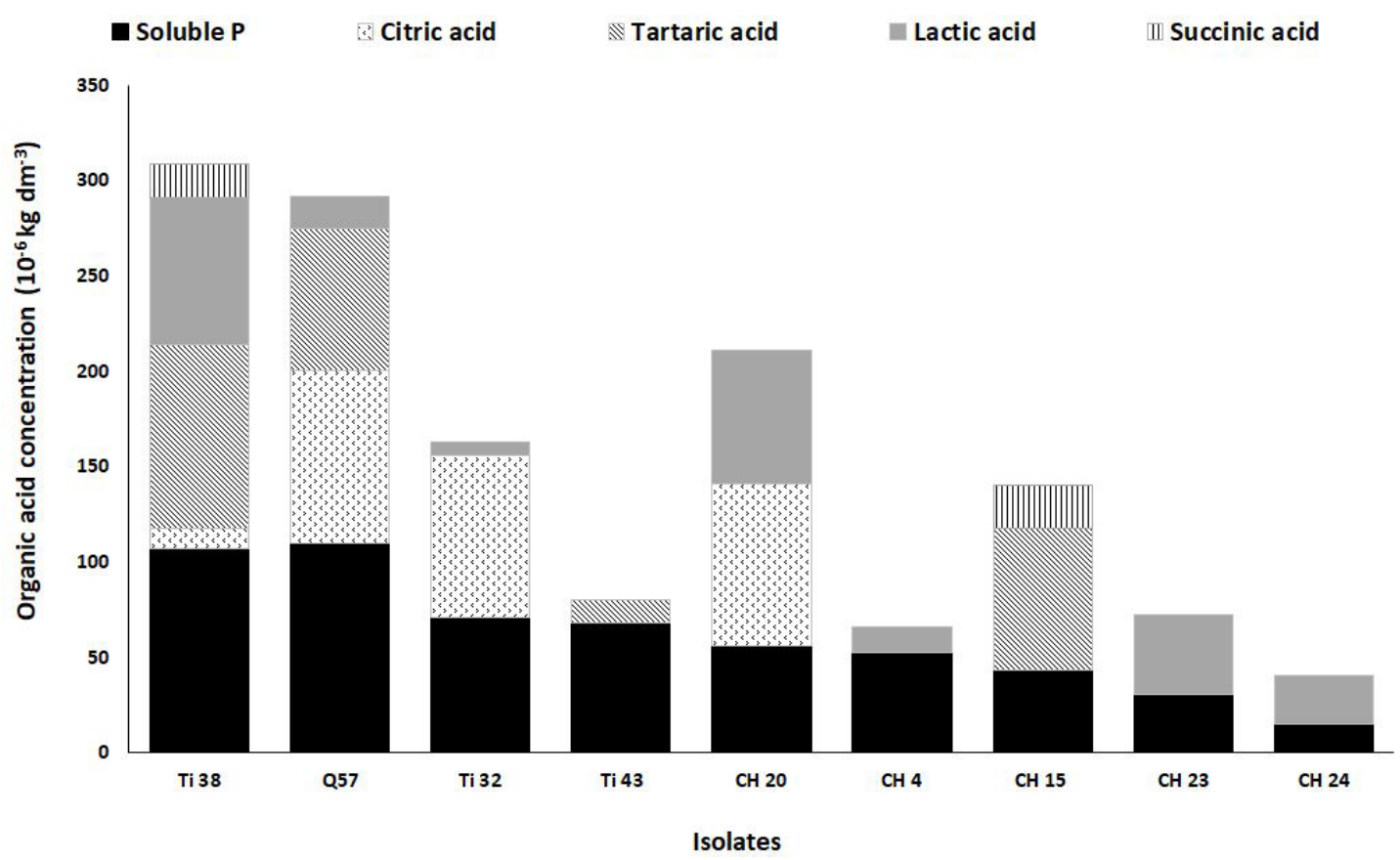

Figure 4: HPLC detection of types and concentrations of organic acids produced by nine contrasting PSF isolates selected from three soils of the central coffee-growing region of Colombia ( $\mathrm{CH}$ : Chinchiná; QU: Quindío and Ti: Timbío). 
According to several authors, organic acids production depends on the microorganism. For example, bacteria of the genus Bacillus have been highlighted for producing lactic, gluconic, and propionic acids (Wyciszkiewicz et al., 2016) and isovaleric, isobutyric, and lactic acids (Calvaruso; Turpault; Frey-Klett, 2006). In contrast, bacteria of the genus Brevibacillus produce gluconic and citric acids (Yadav et al. al., 2013) as well as formic acid, among other acids already mentioned. On the other hand, all of these acids were detected during the dissolution process of phosphate rock inoculated with Serratia sp. (Behera et al., 2017).

Similarly, citric acid has been widely reported to be produced by $A$. niger (Haq; Ali; Iqbal, 2003; Bojinova; Velkova; Ivanova, 2008), oxalic acid has been produced by Mortierella sp. (Osorio; Habte, 2014a), and gluconic acid by Eupenicillium ludwigii (Oliveira et al., 2014). In addition, this is highly dependent on the characteristics of the P-containing mineral in which the PSF develop. For example, fungi of the genus Aspergillus secrete high concentrations of citric acid when they grow in a medium with $\mathrm{Fe}$ and $\mathrm{Al}$ phosphates, but this production was suppressed in the presence of rock phosphate. Similarly, species of Penicillium produce high concentrations of gluconic acid in P-compounds rich in $\mathrm{Ca}$, while they produce low levels of citric acid (Oliveira et al., 2014). In a study performed with PSF isolated from palm plantations in Colombia, the production of gluconic acid and citric acid was predominant by $A$. niger when grew in a medium supplemented with Ca phosphates (Acevedo et al., 2014).

From the above results, the analysis of the organic acids secreted by the PSF indicates an additional means of explaining the solubilization mechanisms of $\mathrm{P}$. These acids not only decrease $\mathrm{pH}$, but also have the capacity to complex the accompanying $\mathrm{P}$ cation present in the mineral (e.g., $\mathrm{Ca}^{2+}$, $\mathrm{Al}^{3+}, \mathrm{Fe}^{2+3+}$ ) (Lazo; Dyer; Alorro, 2017; Lin et al., 2017). The chemical composition of phosphate rock consists of $\mathrm{Ca}$ phosphates, which tend to release phosphate ions for further biological use (plants and microbes) (Equations 2 and 3) according to Osorio (2011).

$\mathrm{Ca}_{5}\left(\mathrm{PO}_{4}\right)_{3} \mathrm{OH}+7 \mathrm{H}^{+}+5$ citrate $\stackrel{\leftarrow}{\leftrightarrows} 5 \mathrm{Ca}$-citrate $+3 \mathrm{H}_{2} \mathrm{PO}_{4}^{-}+\mathrm{H}_{2} \mathrm{O} \quad K=10^{37.9}$

Free energy yield: $-216 \mathrm{~kJ} \mathrm{~mol}^{-1}$

$\mathrm{Ca}_{5}\left(\mathrm{PO}_{4}\right)_{3} \mathrm{OH}+7 \mathrm{H}^{+}+5$ oxalate $\leftrightarrows 5 \mathrm{Ca}$-oxalate $+3 \mathrm{H}_{2} \mathrm{PO}_{4}^{-}+\mathrm{H}_{2} \mathrm{O} \quad K=10^{31.7}$

Free energy yield: $-181 \mathrm{~kJ} \mathrm{~mol}^{-1}$

Based on the free energy yields and the $K$ values of the equations, the presence of protons combined with the organic acids/anions contributes to the phosphate rock dissolution.

\subsection{Phosphate-Solubilizing Fungi growth rate evaluation}

At the end of the evaluation period $(15 \mathrm{~d})$, the strain $\mathrm{CH} 4$ showed the largest colony growth (diameter of $7.7 \mathrm{~cm}$ ) (Figure 5), this only produced lactic acid (monocarboxylic). In contrast, the strain Ti38, which was characterized as the most effective in solubilizing $\mathrm{P}$ and produced the highest concentration and diversity of acids (citric, tartaric, lactic, and succinic acids) exhibited 2.2-fold less growth compared to $\mathrm{CH} 4$. Finally, the strains PSF, Q57, and $\mathrm{CH} 2 \mathrm{O}$ exhibited intermediate colony growth and produced between two and three types of organic acids.

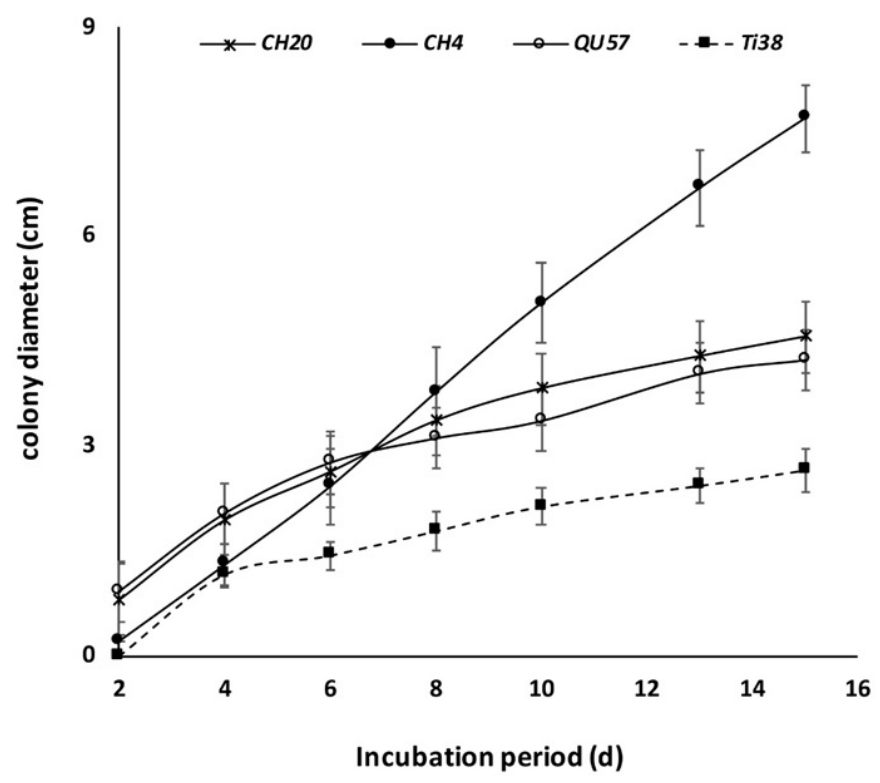

Figure 5: Diameter of fungal colonies as a function of the incubation time after inoculating the medium with five PSF isolates obtained from three soils of the central coffee-growing region of Colombia. Vertical bars indicate $5 \%$ confidence intervals.

These findings indicate that the effective P solubilization can have a significant energy cost. This production and release of acid may occur during the Krebs cycle (Sylvia et al., 1998), generating a "carbon drainage" that may be limiting fungal growth (Deng; Wang; Yan, 2016).

\subsection{Identification of phosphate-solubilizing fungal species}

Three isolates (CH20, Q57, Ti38) showed identity $100 \%$ and the expected value (e-value) equal 0 with the genus Penicillium, while CH4 was identified as Phlebia (Table 2). Fungi of the genus Penicillium, which is one of the most abundant genera in diverse habitats of the planet (Visagie et al., 2014; Coutinho; Felix; Yano-Melo, 2012), have been noted for their ability to solubilize P-containing minerals 
Table 2: The likely identities of the four PSF selected for this study.

\begin{tabular}{|c|c|c|c|c|c|c|c|}
\hline \multirow{2}{*}{ PSF } & Sequence & Identifier & Alignment & \multirow{2}{*}{ e -value } & Identity & \multirow{2}{*}{ Gender } & \multirow{2}{*}{ Species } \\
\hline & (bp) & GenBank & (bp) & & $\%$ & & \\
\hline $\mathrm{CH} 4$ & 651 & KJ831936.1 & 612 & 0 & 100 & Phlebia & subserialis \\
\hline $\mathrm{CH} 20$ & 552 & GU934553.1 & 556 & 0 & 100 & Penicillium & jantinelum \\
\hline QU57 & 536 & KX953360.1 & 535 & 0 & 100 & Penicillium & sp. \\
\hline Ti38 & 538 & NR121514.1 & 541 & 0 & 100 & Penicillium & ubiquetum \\
\hline
\end{tabular}

considered soluble as well as those having poor solubility, such as $\mathrm{Ca}$ phosphates, Fe phosphates and Al phosphates, under laboratory conditions (Jain; Saxena; Sharma, 2014). For phosphates with low solubility, this effect is attributed to the production of citric and gluconic acids (Efthymiou et al., 2018). Oliveira et al. (2014) isolated Penicillium strains from eucalyptus plantations and demonstrated their ability to solubilize $\mathrm{P}$ from $\mathrm{Ca}, \mathrm{Fe}$, and $\mathrm{Al}$ phosphates as well as from phosphate rock of different origins, showing that this effect was governed by the secretion of citric, gluconic, and oxalic acids. These effects have translated from the laboratory to the field, facilitating the absorption of $\mathrm{P}$ in maize and wheat plants, as described by Singh and Reddy (2011).

Specifically, members of the genus Phlebia are recognized for their ability to degrade recalcitrant organic compounds (Xiao et al., 2011), produce ethanol (Tsuyama; Yamaguchi; Kamei, 2017), and transform materials with potential use in agriculture, such as chicken manure (Zhao et al., 2017), but their effectiveness to dissolve RP has not been reported.

\subsection{Association between the proportion of PSF and $\mathrm{P}$ fixation capacity in soil}

The results showed that the number of CFU varied from soil to soil, for instance the soil collected in Quindío presented the highest number of total CFU, that is, with and without $\mathrm{P}$ solubilization capacity, with an average of $50 \mathrm{CFU} \mathrm{g}^{-1}$ of soil, followed by the soil from Chinchiná and Timbío, with average values of 18 and $3 \mathrm{CFU} \mathrm{g}^{-1}$, respectively (Figure 6). From those isolates detected respectively in Chinchina, Timbío and Quindio 100, 35 and 5\% corresponded to PSF (Figure 7).

These results suggest that the soil $\mathrm{P}$ fixation capacity is a factor that determines the abundance of PSF, this was measured as the amount of $\mathrm{P}\left(10^{-6} \mathrm{~kg} \mathrm{dm}^{-3}\right)$ required to reach $\mathrm{P}_{0.2}$ was Chinchina $\geq$ Timbío $>$ Quindio (Table 3 ). However, the similarity between the fixation of P in the soil from Chinchiná and Timbío showed that soil organic matter could constitute another important variable. Thus, the presence of labile carbonaceous substances that constitute a raw material to efficiently guarantee metabolic processes that favor the P dissolution by PSF (Gaind, 2016) may be responsible for this phenomenon, given that PSF are heterotrophic organisms (Sylvia et al., 1999).

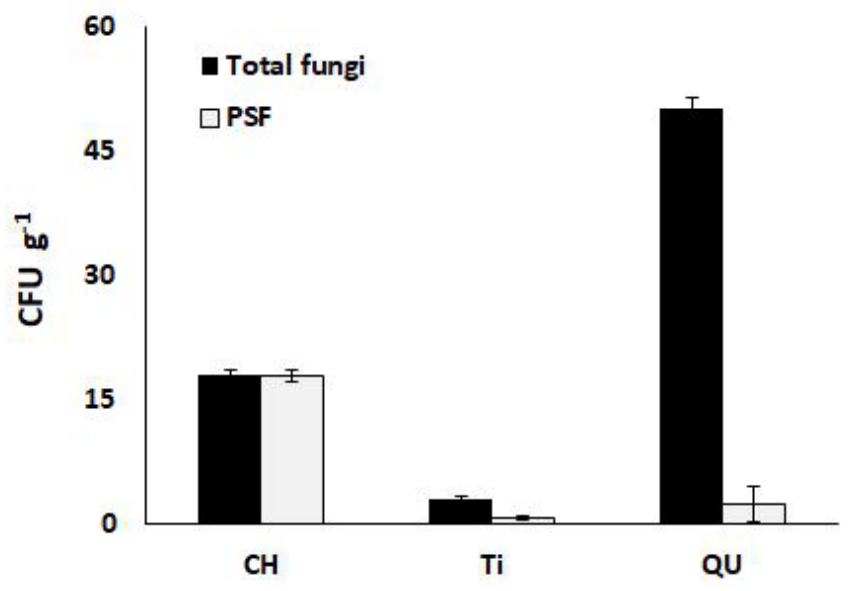

Figure 6: Number of colonies forming units (CFU) and PSF in the studied soils.

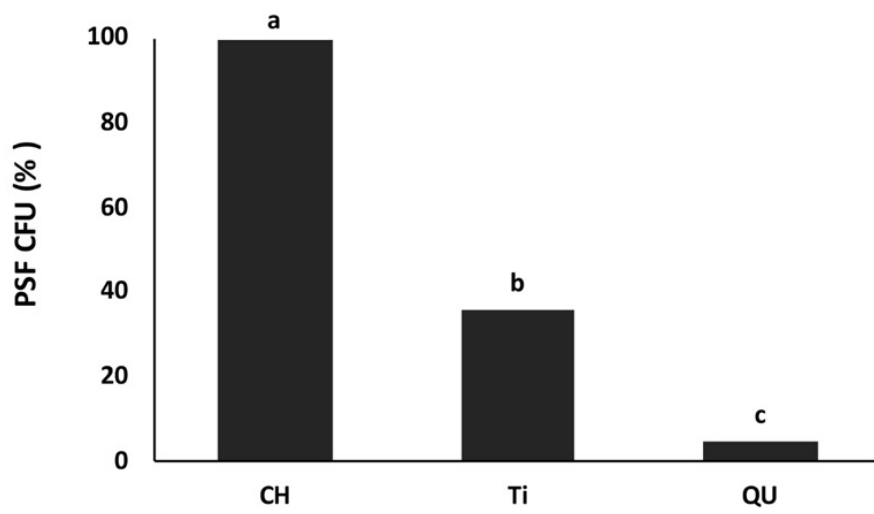

Figure 7: Relative proportion of PSF in the studied soils. Different letters indicate a significant difference according to Duncan's test $(P<0.0001)$.

Under this scenario, organic compounds that serve as a source of $\mathrm{C}$ and energy for PSF may be limited in Timbío where the organic matter content $(18 \%)$ is markedly higher than that in Chinchiná with a value of $12 \%$. That is, high levels of organic matter may correspond to a low mineralization rate as a consequence of the humus-type substances that form the stable fraction. Consequently, there will be fewer sources of $\mathrm{C}$ readily available for microorganisms (Berg, 2018; Kumar; Rai, 2017).

Evidence for this phenomenon was included in the taxonomy of the Andisols. Thus, soils classified within the 
grand group Fulvudands (e.g., Chinchiná) have organic matter less humic than those classified as Melanudand (e.g., Timbio) (Shoji; Nanzyo; Dahlgren, 1994). This difference can also be observed in the melanic index (Table 3), which exhibited a decreasing order: Chinchiná (1.9)> Quindio (1.8) > Timbío (1.6). As the MI decreases, there is a higher level of humification, which means less bioavailability of the organic $\mathrm{C}$ in the soil.

Table 3: Values of IM, pH, OM, and P fixation found in the soil studied.

\begin{tabular}{cccccc}
\hline Soil & $\mathrm{MI}^{\dagger}$ & $\mathrm{pH}$ & $\mathrm{OM}$ & $\mathrm{P}_{0.2}$ value & Soil P fixation \\
\cline { 5 - 6 } & & & $\%$ & $\left(10^{-6} \mathrm{~kg} \mathrm{dm}^{-3}\right)^{\dagger \dagger}$ & $\begin{array}{c}\text { Category } \\
\text { Q⿱亠巾十 }\end{array}$ \\
\hline Quindío (QU) & 1.8 & 5.2 & 6 & 374 & Moderate \\
Chinchiná (CH) & 1.9 & 4.6 & 12 & 619 & High \\
Timbío (Ti) & 1.6 & 5.2 & 18 & 615 & High \\
\hline
\end{tabular}

$\dagger$ Melanic index: determined through the $450 / 520 \mathrm{~nm}$ absorbance ratio. $\dagger+P_{0.2}$ value $=$ amount of $P\left(10^{-6} \mathrm{~kg} \mathrm{dm}^{-3}\right)$ required to achieve a soil solution $\mathrm{P}$ concentration of $0.2 \times 10^{-6} \mathrm{~kg} \mathrm{dm}^{-3}$ (Fox; Kamprath, 1970). †† Soil $\mathrm{P}$ fixation category according to the Juo and Fox proposal.

On the other hand, the Quindío soil was characterized by a low P fixation, intermediate MI, a low level of organic matter resulting from a likely higher rate of mineralization that may explain the abundance of fungi. This also would also generate in a high competition among soil microorganisms for resources $(\mathrm{C}$, other nutrients, water, space). Thus, the PSF must develop strategies to acquire the phosphate necessary for cellular synthesis and metabolism, including the secretion of organic acids (Chiou; Lin, 2011; Li et al., 2009) or phytases (Jain; Pandey, 2016). Phytases are a specific group of phosphatases that act upon phytates hydrolyzing the ester bond between phosphate and $\mathrm{C}$ in the organic matter, allowing the release of phosphate to be further used for microorganisms and plants. This mechanism may be observed in the high P-fixation environments previously discussed.

In summary, the soil $\mathrm{P}$ fixation and the contents and types of organic matter (labile or stable) can explain the greater abundance of PSF in soils derived from volcanic ash. Respect to the variability of $\mathrm{P}$ fixation, the results are consistent with those described by Osorio and Habte (2014b), who identified microorganisms in an Andisol with a high capacity to fix $\mathrm{P}\left(\mathrm{P}_{0.2}\right.$ : $1100 \times 10^{-6} \mathrm{~kg} \mathrm{dm}^{-3}$ ) and a greater ability to dissolve phosphatic rock than those present in an Oxisol $\left(\mathrm{P}_{0.2}: 350 \times 10^{-6} \mathrm{~kg} \mathrm{dm}^{-3}\right)$ and particularly greater than those present in a Mollisol $\left(\mathrm{P}_{0.2}: 120 \mathrm{x}\right.$ $10^{-6} \mathrm{~kg} \mathrm{dm}^{-3}$ ) with moderate and low $\mathrm{P}$ fixation.

\section{CONCLUSIONS}

The decrease of the medium $\mathrm{pH}$ during the screening for effective PSF did not satisfactorily explain the potential for phosphate rock solubilization. Thus, it is necessary other factors such as the concentration and diversity of the organic acids produced by the PSF.

The fungal growth rate under laboratory conditions should not be considered as the only selection criterion for effective PSF. In fact, given the production of organic acids constitutes a significant $\mathrm{C}$ drainage for PSF, limiting the fungal growth.

In soils cultivated with coffee in Colombia Phlebia genus is reported, for the first time, as a PSF. Penicillium spp. were also detected as PSF in this agroecosystem, this genus has been amply reported for doing so.

In Andisols, the relative abundance of PSF seems to be associated to the very high levels of P fixation capacity, the soil organic matter content and its humification degree.

\section{ACKNOWLEDGMENTS}

The authors wish to thank the Doctoral Program of Biotechnology in the Universidad Nacional de Colombia at Medellín, the National Coffee Research Center (CENICAFE) where this project was conducted, and the Colombian Institute for the Advancement of Science and Technology (COLCIENCIAS) for a Ph.D. fellowship $\mathrm{N}^{\circ} 617$ awarded to Hernan Gonzalez during his doctoral studies.

\section{REFERENCES}

ACEVEDO, E. et al. Phosphate-solubilizing microorganisms associated with the rhizosphere of oil palm (Elaeis guineensis Jacq.) in Colombia. Applied Soil Ecology, 80:26-33, 2014.

ADELEKE, R.; NWANGBURUKA, C.; OBOIRIEN, B. Origins, roles and fate of organic acids in soils: A review. South African Journal of Botany, 108:393-406, 2017.

ALTSCHUL, S. F. et al. Basic local alignment search tool. Journal of Molecular Biology, 215(3):403-410, 1990.

AL-THYABAT, S.; ZHANG, P. In-line extraction of REE from Dihydrate (DH) and Hemi Dihydrate (HDH) wet processes. Hydrometallurgy, 153:30-37, 2015.

ARRIETA, A. M. et al. A foliar endophyte increases the diversity of phosphorus-solubilizing rhizospheric fungi and mycorrhizal colonization in the wild grass Bromus auleticus. Fungal Ecology, 17:146-154, 2015.

AUNG, K. M. M.; TING, Y. P. Bioleaching of spent fluid catalytic cracking catalyst using Aspergillus niger. Journal of Biotechnology, 116(2):159-170, 2005. 
BEHERA, B. C. et al. Phosphate solubilization and acid phosphatase activity of Serratia sp. isolated from mangrove soil of Mahanadi river delta, Odisha, India. Journal of Genetic Engineering and Biotechnology, 15(1):169-178, 2017.

BELBOOM, S.; SZÖCS, C.; LÉONARD, A. Environmental impacts of phosphoric acid production using dihemihydrate process: A Belgian case study. Journal of Cleaner Production, 108:978-986, 2015.

BERG, B. Decomposing litter; limit values; humus accumulation, locally and regionally. Applied soil ecology, 123:494-508, 2018.

BOJINOVA, D.; VELKOVA, R.; IVANOVA, R. Solubilization of Morocco phosphorite by Aspergillus niger. Bioresource Technology, 99(15):7348-7353, 2008.

BÜNEMANN, E. K. Assessment of gross and net mineralization rates of soil organic phosphorus - A review. Soil Biology and Biochemistry, 89:82-98, 2015.

CALVARUSO, C.; TURPAULT, M. P.; FREY-KLETT, P. Rootassociated bacteria contribute to mineral weathering and to mineral nutrition in trees: a budgeting analysis. Applied and Environmental Microbiology, 72(2):1258-1266, 2006.

CHIOU, T. J.; LIN, S. I. Signaling network in sensing phosphate availability in plants. Annual Review of Plant Biology, 62:185-206, 2011.

CORDELL, D.; DRANGERT, J. O.; WHITE, S. The story of phosphorus: Global food security and food for thought. Global Environmental Change, 19(2):292-305, 2009.

COUTINHO, F. P.; FELIX, W. P.; YANO-MELO, A. M. Solubilization of phosphates in vitro by Aspergillus spp. and Penicillium spp. Ecological Engineering, 42:85-89, 2012.

DENG, W.; WANG, Y.; YAN, N. Production of organic acids from biomass resources. Current Opinion in Green and Sustainable Chemistry, 2:54-58, 2016.

DWIVEDI, B. S.; SINGH, V. K.; DWIVEDI, V. Application of phosphate rock, with or without Aspergillus awamori inoculation, to meet phosphorus demands of rice-wheat systems in the Indo-Gangetic plains of India. Australian Journal of Experimental Agriculture, 44(10):10411050, 2004.

EFTHYMIOU, A. et al. Augmentation of the phosphorus fertilizer value of biochar by inoculation of wheat with selected Penicillium strains. Soil Biology and Biochemistry, 116:139-147, 2018.
ESTRADA, B. et al. Effect of phosphate-solubilizing bacteria on phosphorus dynamics and the bacterial community during composting of sugarcane industry waste. Systematic and Applied Microbiology, 40(5):308-313, 2017.

FEDERACIÓN NACIONAL DE CAFETEROS DE COLOMBIA - FNC. Manual del cafetero colombiano: Investigación y tecnología para la sostenibilidad de la caficultura. Chinchiná Colombia, Federación Nacional de Cafeteros de Colombia, vol. 1. 321p. 2013.

FOX, R. L.; KAMPRATH, E. J. Phosphate sorption isotherms for evaluating the phosphate requirements of soils. Soil Science Society of America Journal, 34(6):902-907, 1970.

GAIND, S. Phosphate dissolving fungi: Mechanism and application in alleviation of salt stress in wheat. Microbiological Research, 193:94-102, 2016.

GONZALEZ, O. H. Biotechnological alternatives to improve phosphorus (P) fertilization efficiency in coffee growing. Ph.D. Thesis, Universidad Nacional de Colombia, Medellin, 127 p. 2018.

HAQ, I. U.; ALI, S.; IQBAL, J. Direct production of citric acid from raw starch by Aspergillus niger. Process Biochemistry, 38(6):921-924, 2003.

INTERNATIONAL FERTILIZER ASSOCIATION - IFA. Fertilizer outlook 2013-2017. 81 IFA annual conference. Chicago (USA), 20-22 may. 632p. 2013.

JAIN, R.; PANDEY, A. Soil enzymes and microbial endophytes as indicators of climate variation along an altitudinal gradient with respect to wheat rhizosphere under mountain ecosystem. Rhizosphere, 2:75-84, 2016.

JAIN, J.; SINGH, B. Characteristics and biotechnological applications of bacterial phytases. Process Biochemistry, 51(2):159-169, 2016.

JAIN, R.; SAXENA, J.; SHARMA, V. Differential effects of immobilized and free forms of phosphate-solubilizing fungal strains on the growth and phosphorus uptake of mung bean plants. Annals of microbiology, 64(4):15231534, 2014.

JUO, A. S. R.; FOX, R. L. Phosphate Sorption Characteristics Of Some Bench-Mark Soils Of West Africa. Soil Science, 124(6):370-376, 1977.

KHAN, M. S. et al. Plant growth promotion by phosphate solubilizing fungi-current perspective. Archives of Agronomy and Soil Science, 56(1):73-98, 2010. 
KUMAR, A.; RAI, L. C. Soil Organic Carbon and Availability of Soil Phosphorus Regulate Abundance of Culturable Phosphate Solubilizing Bacteria in Paddy Fields of the Indo-Gangetic Plain. Pedosphere, 30(3):405-413, 2017.

LAZO, D. E.; DYER, L. G.; ALORRO, R. D. Silicate, phosphate and carbonate mineral dissolution behaviour in the presence of organic acids: A review. Minerals Engineering, 100:115-123, 2017.

LIN, B. et al. Effects of organic acids of different molecular size on phosphate removal by HZO-201 nanocomposite. Chemosphere, 166, 422-430, 2017.

LI, X. F. et al. Secretion of citrate from roots in response to aluminum and low phosphorus stresses in Stylosanthes. Plant and Soil, 325(1-2):219-229, 2009.

MATTA, S. et al. Phosphoric acid production by attacking phosphate rock with recycled hexafluosilicic acid. International Journal of Mineral Processing, 161: 21-27, 2017.

MAHECHA-VÁSQUEZ, G.; SIERRA, S.; POSADA, R. Diversity indices using arbuscular mycorrhizal fungi to evaluate the soil state in banana crops in Colombia. Applied Soil Ecology, 109, 32-39, 2017.

MILLER, A. P.; ARAI, Y. Effects of extraction time and phosphorus speciation on soil test phosphorus data: A case study of Illinois agricultural soils. Geoderma, 305:62-69, 2017.

MITTAL, V. et al. Stimulatory effect of phosphate-solubilizing fungal strains (Aspergillus awamori and Penicillium citrinum) on the yield of chickpea (Cicer arietinum L. cv. GPF2). Soil Biology and Biochemistry, 40(3):718-727, 2008.

MORA, M. L. et al. Aluminum-tolerant bacteria improve the plant growth and phosphorus content in ryegrass grown in a volcanic soil amended with cattle dung manure. Applied Soil Ecology, 115:19-26, 2017.

OLIVEIRA, M. G. et al. Mechanisms of phosphate solubilization by fungal isolates when exposed to different P sources. Annals Microbiol, 64(1):239-249, 2014.

OSORIO, V. N. W. Effectiveness of Phosphate Solubilizing Microorganism in Increasing Plant Phosphate Uptake and Growth in Tropical Soils. In: DINESH, M. (Ed.). Bacteria in Agrobiology: Plant nutrient management. Springer NY (USA). 65-80. 2011.

OSORIO, N. W.; HABTE, M. Effect of a phosphate-solubilizing fungus and an arbuscular mycorrhizal fungus on leucaena seedlings in tropical soils with contrasting phosphate sorption capacity. Plant and Soil, 389(1-2):375-385, 2014a.
OSORIO, N. W.; HABTE, M. Soil phosphate desorption induced by a phosphate-solubilizing fungus. Communications in Soil Science and Plant Analysis, 45(4):451-460, 2014b.

OSORNO, L.; OSORIO, N. W. Effect of carbon and nitrogen source and concentration on rock phosphate dissolution induced by fungi. Journal of Applied Biotechnology, 2(2):32, 2014.

OWEN, D. et al. Use of commercial bio-inoculants to increase agricultural production through improved phosphrous acquisition. Applied Soil Ecology, 86:41-54, 2015.

PIKOVSKAYA, R. I. Mobilization of phosphorus in soil in connection with vital activity of some microbial species. Mikrobiologiya, 17:362-370, 1948.

ROLEWICZ, M.; RUSEK, P.; BOROWIK, K. Obtaining of granular fertilizers based on ashes from combustion of waste residues and ground bones using phosphorous solubilization by bacteria Bacillus megaterium. Journal of Environmental Management, 216:128132, 2017.

ROY, E. D. et al. Soil phosphorus sorption capacity after three decades of intensive fertilization in Mato Grosso, Brazil. Agriculture, Ecosystems \& Environment, 249:206-214, 2017.

\section{SARAVANAKUMAR, K.; ARASU, V. S.; KATHIRESAN,} K. Effect of Trichoderma on soil phosphate solubilization and growth improvement of Avicennia marina. Aquatic Botany, 104:101-105, 2013.

\section{SHOJI, S.; NANZYO, M.; DAHLGREN, R. Volcanic ash} soils: Genesis, properties and utilization. Amsterdam Holanda, Elsevier, vol. 21, 288p. 1994.

SHOJI, S.; TAKAHASHI, T. Environmental and agricultural significance of volcanic ash soils. Global Environmental Research-English Edition, 6(2):113135, 2002.

SINGH, H.; REDDY, M. S. Effect of inoculation with phosphate solubilizing fungus on growth and nutrient uptake of wheat and maize plants fertilized with rock phosphate in alkaline soils. European Journal of Soil Biology, 47(1):30-34, 2011.

STAMFORD, N. P. et al. Agronomic effectiveness of biofertilizers with phosphate rock. Bioresource and Biotechnology, 98(9):1311-1318, 2007.

SYLVIA, M. D. et al. Principles and applications of soil microbiology. 1.ed. Upper Saddle River USA, Pearson Prentice Hall, 550p. 1998. 
TIAN, J. et al. Accumulation and distribution of phosphorus in the soil profile under fertilized grazed pasture.

Agriculture, Ecosystems \& Environment, 239:228-235, 2017.

TSUYAMA, T.; YAMAGUCHI, M.; KAMEI, I. Accumulation of sugar from pulp and xylitol from xylose by pyruvate decarboxylese-negative white-root fungus Phlebia sp. MG60. Bioresour Technol, 238:241-247, 2017.

VELÁSQUEZ, G. et al. Chemical nature of residual phosphorus in Andisols. Geoderma, 271:27-31, 2016.

VISAGIE, C. M. et al. Identification and nomenclature of the genus Penicillium. Studies in Mycology, 78:343-371, 2014.

WENDLING, L. A. et al. Phosphorus sorption and recovery using mineral-based materials: sorption mechanisms and potential phytoavailability. Applied Geochemistry, 37:157-169, 2013.

WHITELAW, M. A. Growth promotion of plants inoculated with phosphate-solubilizing fungi. Advances in Agronomy, 69:99-151, 1999.

WYCISZKIEWICZ, M. et al. Utilization of microorganisms in the solubilization of low-quality phosphorus raw material. Ecological Engineering, 89:109-113, 2016.

XIAO, P. et al. Novel metabolic pathways of organochlorine pesticides dieldrin and aldrin by the white rot fungi of the genus Phlebia. Chemosphere, 85(2):218-224, 2011.

XIAO, C. Q. et al. Optimization for rock phosphate solubilization by phosphate-solubilizing fungi isolated from phosphate mines. Ecological Engineering, 33(2):187-193, 2008.

YADAV, H. et al. Optimization of culture conditions for phosphate solubilization by a thermo-tolerant phosphatesolubilizing bacterium Brevibacillus sp. BISR-HY65 isolated from phosphate mines. Biocatalysis and Agricultural Biotechnology, 2(3):217-225, 2013.

ZHAO, L.; ZHANG, Y. Q. Effects of phosphate solubilization and phytohormone production of Trichoderma asperellum Q1 on promoting cucumber growth under salt stress. Journal of Integrative Agriculture, 14(8):1588-1597, 2015.

ZHAO, K. et al. Development of a novel compound microbial agent for degradation of kitchen waste. Brazilian Journal of Microbiology, 48(3):442-450, 2017. 